\title{
Economic Growth and Sectoral Capacity for Employment Creation in Zambia
}

\author{
Oluyele Akinkugbe \\ University of the Witwatersrand, South Africa
}

\begin{abstract}
Available statistics show that Africa's rate of growth has consistently outperformed the global rate over the last decade; World Bank Global Economic Prospects 2014 reports that the growth rate in subSaharan Africa (SSA) is expected to improve to 5.1 percent in 2016, from an estimated flat rate of sub-5 percent in 2014 and 2015. Similarly, a combination of prudent macroeconomic management, market liberalization and privatization efforts, investments in the copper industry and related infrastructure, and steep increase in copper prices coupled with growth in exports, helped Zambia achieve an average annual growth of about 5.7 percent during the last decade. However, Zambia's high growth economic performance has not translated into significant poverty reduction; the sustained growth has not been inclusive and on the other hand, had been accompanied by lack of access to wage income as implied by low employment opportunities (for the youth in particular), in the formal sector. This paper assesses the historical capacity of the different sectors of the Zambian economy to absorb labour. This involves a review of growth trends in the economic sub-sectors and computation of employment elasticity of growth. It follows from results of our analysis that to deal with Zambia's youth unemployment challenges, targeted measures would have to be directed at removing impediments to growth in sectors with relatively high employment elasticity.
\end{abstract}

\section{Introduction}

Conventional wisdom has it that the major link through which economic growth translates to poverty reduction and equality of opportunities in an economy is in the amount of employment it generates. Hence, when sustained growth is not accompanied by employment creation, it remains non-inclusive such that unemployment may be stubbornly high even as the economy grows. Furthermore, consensus in the rich and growing literature on the relationship between economic growth and poverty reduction is that output growth is a necessary but not sufficient condition for a country to improve the standards of living of its people [1]. An inclusive growth strategy that ensures gradual reduction in inequality and expanding job opportunities is considered an important factor in the fight against poverty as an economy grows. The point of emphasis in the linkage between employment creation, inclusive growth and poverty reduction outcomes is that the poor derive their incomes from paid employment, especially in the formal sector; employment tends to serve as that crucial bridge that connects economic growth and poverty reduction, since labour service is the main asset for majority of the poor. Hence, the level of employment and the access of the poor to decent earning opportunities are crucial determinants of poverty alleviation and sustained reduction in inequality.

Since the mid-1990s, intuition that the creation of jobs matters for development underlies the design of a vast majority of national development plans and strategies in most African countries that look to employment generation as a major channel for poverty reduction. For instance, a major goal expressed in Zambia's Vision 2030 is to achieve middle income status by 2030 [2]. To achieve this and also overcome the high level of employmentyouth unemployment in particular - the Government has to address the constraints to increasing production levels in the private sector such that more formal sector jobs could become available. The idea is that for sustained economic growth to generate the kind of employment that contributes directly to poverty alleviation; sectors that have relatively high elasticities of employment must be the drivers of growth. While existing literature seems unanimous that sectoral patterns of growth affect the extent of poverty reduction, there remains a lack of consensus on which sector(s) are most important. While Loayza and Raddatz [3], find that growth in labour-intensive sectors such as agriculture, contributes more to poverty reduction, Satchi and Temple [4] are of the view that growth in agriculture may increase poverty even further if, while growth in the urban sectorbased service and manufacturing activities may cause it to fall. 
This paper seeks to examine for Zambia, what the statistics say in terms of the responsiveness of employment to sectoral output growth over the years, and which sector(s) have performed better in terms of creating more jobs. To achieve this, the paper examines the extent to which Zambia's impressive growth rates of the last decade has been accompanied by increases in employment and the key sectors driving growth.

\section{Output growth and labour market dynamics: earlier literature}

The relationship between output growth and labour market performance may be said to have gained popularity with the seminal work of Okun [5], in which the famous " Okun's law"-each percentage point above full employment is associated with a fall of about three per cent in real gross national product (GNP)—was formulated . Although this link was essentially given the status of an empirical regularity, the approach was implicitly "supply-side" oriented [6], the deviation of the unemployment rate from its natural level being assumed to induce a certain deviation of output from its long-run (or equilibrium) trend ("potential" GNP). Subsequent studies on the subject focused on the direction of causality between the variables, ([7], etc.). Many of these contributors adopted output growth rates as the exogenous and unemployment rates as the endogenous variables in their analyses.

Although the direct relationship between growth and employment is not as popular as Okun's law, it has gained increasing interest in recent years given the policy relevance of the issue; the targets of the European Employment Strategy (EES) for instance, launched at the 2000 Lisbon Council, were set in terms of employment rates [8]. Its simplest formulation relies upon the familiar concept of elasticity; a responsiveness index that in this case, describes the per cent reaction of employment to a one per cent change in output. The concept of elasticity implies per se a casual direction (in the framework of a demand-side approach); vice versa, the common approach considers the labour-output relationship in a production function context, i.e., labour is one input, and productive circumstances determine the output elasticity to the factors employed.

However, the employment intensity (or elasticity) of growth can also be simply used, together with other traditional labour market indicators (employment and unemployment rates), as a measure of how employment and output vary together over As a result, many young Africans find themselves unemployed or more frequently underemployed in time. From this point of view, the relationship may be interpreted in terms of correlation, rather than causality, [10]). Theoretical considerations may be re-integrated ex post by studying the determinants of employment intensity and examining, first of all, the role of technology, since the productivity intensity of growth is clearly the other side of the coin, [11]. But the importance of structural factors (e.g., industry composition of the economic system), labour costs, labour market institutions and their dynamics, and other macroeconomic factors must also be considered.

Further, authors, such as Islam and Nazara [12], Ajilore and Yinusa [13], etc., caution that employment elasticity has overtly overemphasised employment growth over productivity growth. Whereas the employment intensity of growth is a purely quantitative aspect of job rich growth, productivity growth speaks more to the qualitative aspects of growth in the number of 'decent' jobs. In this regard, the authors emphasise that both the employment and productivity-intensive growth are desirable in order to produce economic development objectives such as poverty reduction and reduction of social exclusion (see [1], [3] and [11].

\section{Macroeconomic background}

Recent figures from the African Development Bank (AfDB), the World Bank, and the International Monetary Fund (IMF), show that Africa's rate of growth has outperformed the global rate over the last decade. From 2001 to 2010, six of the world's ten fastest-growing economies were in sub-Saharan Africa. Even though the World Bank Global Economic Prospects 2014 reports that the growth rate in sub-Saharan Africa (SSA) is expected to improve to 5.1 percent in 2016, from an estimated flat rate of sub-5 percent in 2014 and 2015, these rates are still much higher that the projected 2.4 and 2.5 percent for the high-income countries in 2015 and 2016 respectively, [13]. However, this high rate of growth is yet to be sufficient enough to guarantee productive employment for all; significant proportion of Africa's population, and particularly the young, are being left behind, remain unemployed, and are becoming frustrated by the day.

Although many jobs have been created on the continent, these have not been enough to accommodate the number of young people in search of work. The International Labour Organization (ILO) estimates that between 2000 and 2008, Africa created 73 million jobs, but only 16 million for young people aged between 15 and 24 [14]. informal jobs, with low productivity and pay. Of Africa's unemployed, 60 percent are young people 
and youth unemployment rates are double those of adult unemployment in most African countries. The problem is particularly acute in middle-income countries (MICs). According to the African Development Bank, for North Africa in 2009, youth unemployment was 23.4 percent, and the ratio of youth-to-adult unemployment rate was estimated at 3.8. In Zambia, youth unemployment was 48 percent in 2010, and the ratio of youth-to-adult unemployment rate was estimated at 2.5. Furthermore, among the employed youth in Zambia, the proportion of those in informal sector jobs is significantly higher than that of adults.

A combination of prudent macroeconomic management, market liberalization and privatization efforts, investments in the copper industry and related infrastructure, and steep increase in copper prices coupled with growth in exports, helped Zambia achieve an average annual growth of about 5.7 percent during the last decade. Real gross domestic product (GDP) growth is projected to increase to 7.1 percent and 7.4 percent in 2014 and 2015 respectively, picking up from the 6.5 percent recorded in 2013, [15]. Infrastructure investment, especially in mining, power generation, and roads will ensure that growth remains robust in coming years. Similarly, inflation is expected to remain in single digits, at 6.8 percent and 6.3 percent respectively, in 2014 and 2015, down from 7.1 in 2013, [16]. The tertiary sector, comprising mainly of services-wholesale and retail trade, restaurants, bars and hotels, transport, storage and communications, financial and real estate services and community, social and personal services-has dominated the economy since the early 1990s; from a contribution of 43.6 percent in 1990, the services sector's contribution peaked at 52 percent in 2012 .

There is therefore no doubt that deliberate government policies since the 1990s are leading to sustained structural transformation and diversification of the Zambian economy. World Bank and statistics further showed that foreign direct investment (FDI) into Zambia rose from approximately US\$ 164.9 million in 2003 to US\$ 1.9 billion in 2013, with most investments going to mining, manufacturing, wholesale and retail trade (see [15]). The outlook for the Zambian economy remains favourable in the medium term, underpinned by this decade-long robust growth and single-digit inflation.

On another note, reviewed statistics reveal that Zambia's economic growth of the last two decades has not translated into significant poverty reduction; the surge in FDI inflows has not manifested in significant formal sector job creation and reduction in unemployment levels. In short, the sustained growth has not been inclusive; it has on the other hand been accompanied by lack of access to wage income as implied by low employment opportunities for the youth in particular, in the formal sector. Sixty percent of the population lives below the poverty line, and 42 percent are considered to be in extreme poverty. About 300, 000 young people enter the labour market each year in Zambia, and with few employment opportunities, the large number of unemployed youth are growing restive by the day.

From the foregoing, concrete steps need to be taken by the Government and other relevant institutions and agencies in Zambia to stem the situation in which the high youth unemployment and slow progress in poverty reduction continues to overshadow the gains made from strong growth and limited inflation in the country. This constitutes a key recommendation of this paper.

\section{Structure of the labour market and current employment situation}

In 2008, the working age population of Zambia stood at 6.7 million people, a little above the 6.2 million recorded in 2005 . This population is made up of those citizens aged between 15 and 64 years who are able and willing to work. It includes the employed, the unemployed and the noneconomically active (Table 1). The number of people in the labour force (i.e. both employed and unemployed labour market participants) increased marginally from 4.9 million in 2005 to 5.0 million in 2008. Of these, 4.6 million were employed and 397,025 million unemployed in 2008. The remaining working age-population aged 15 and abovepopulation of 1.7 million was non-economically active, which is an indication of relatively high participation rates, when compared with other countries in the Southern African Region. The unemployment rate in the country declined from 16 percent in 2005 to 7.9 percent in 2008, if informal sector employment levels are included.

Table 1. Key labour market indicators in Zambia, 2005- 2008

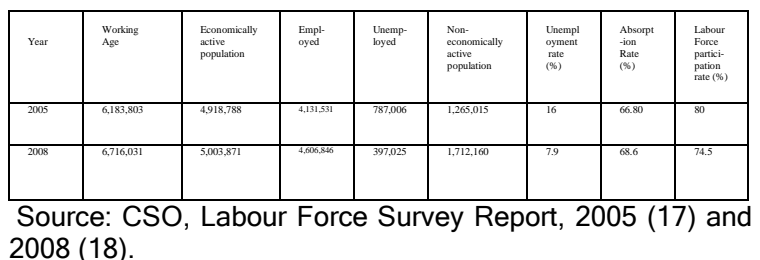

Tables 2 and 3 show that informal sector employment represent about 89 percent of total employment in Zambia in 2008. On the one hand, 
and depending on how this sector of the economy is conceptualized, and how the data in the labour force survey report is put together, this situation of very high informal sector employment could be synonymous with a large small and medium scale enterprises (SMME) sub-sector in the economy. As the case is in many countries around the world, a thriving SMME sector could swiftly translate into a growing middle class in the society. Available evidence from the African Development Bank [19] does indicate that indeed the middle class has been growing in Zambia, just as in other African countries. On the other hand moreover, the high level of poverty and inequality in the economy may be indicative of a significantly high level of disguised unemployment in the informal sector. Whichever way one chooses to interrogate the formal and informal employment statistics in tables 1 and 2, there is no doubt that creating the enabling environment for labour absorption in the economy (using supply and demand side strategies) will in no small way provide the impetus for achieving desired objectives of Zambia's Vision 2030.

\section{Table 2. Percentage distribution of currently employed persons aged 15 years and above by sex and sector of employment, 2008}

\begin{tabular}{|l|l|l|l|l|l|}
\hline \multirow{2}{*}{ Sex } & \multicolumn{2}{|l|}{ Formal Employment } & \multicolumn{2}{c|}{ Informal Employment } & $\begin{array}{l}\text { Employed } \\
\text { Persons }\end{array}$ \\
& & & & \\
& Number & Percent & Number & Percent & \\
\hline Zambia & 511,338 & 11.0 & $4,095,508$ & 89.0 & $4,606,846$ \\
\hline Male & 369,882 & 15.0 & $2,021,903$ & 85.0 & $2,391,785$ \\
\hline Female & 141,456 & 6.0 & $2,073,605$ & 94.0 & $2,215,061$ \\
\hline
\end{tabular}

\subsection{Youth Unemployment}

An important characteristic of Zambia's unemployment crisis is its concentration in the 15-34 age cohort; more of a problem of "youth unemployment", if the definition of "the youth" in the Zambia context is adopted. The Zambian labour force survey 2008 showed that the 15-24 age group accounts for 57 percent of aggregate unemployment, and the 25-34 age group for 29 percent or 2.7 million (Figure 1). In aggregate, this implies that the 15-34 age cohort represents about 86 percent of Zambia's unemployed. If those currently undergoing training are added, this figure rises to 4.1 million. Hence, about 2.7 million young people in the 15-34 age cohort (unemployed and those employed in the informal sector) need to be targeted within the framework of a wage-income employment strategy for the youth, [19].

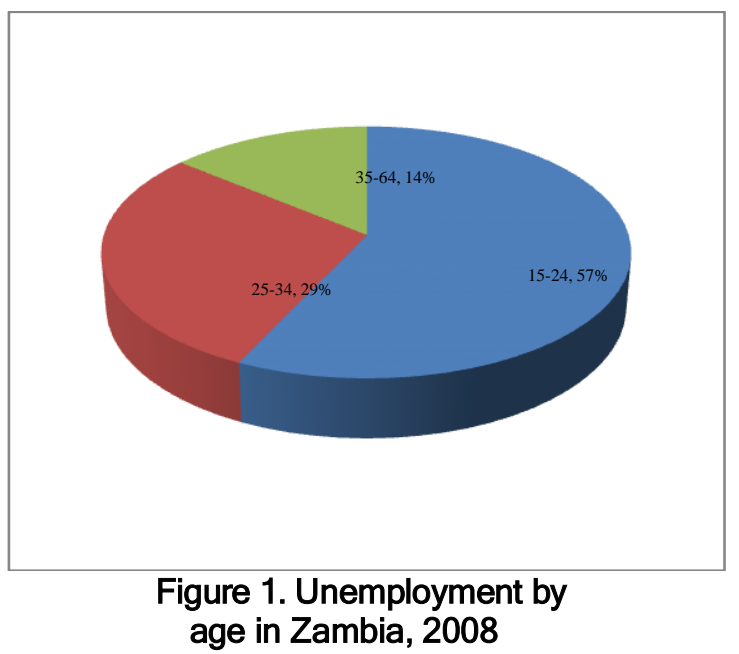

Given that expenditure on education has increased in the last two decades, the unemployed youth have higher educational qualifications than older citizens who are employed. Therefore, the fact that bettereducated young people remain unemployed and poor suggests that the labour market has not been playing a successful role in alleviating poverty and that the education system might not have been delivering the skills needed in the labour market, (see [4]).

Table 3. Informal employment situation, 2008

\begin{tabular}{|c|c|c|c|c|c|c|}
\hline Age/Gender & $\begin{array}{l}\text { Population } \\
\end{array}$ & $\begin{array}{l}\text { Working } \\
\text { Agce }\end{array}$ & 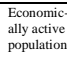 & $\begin{array}{l}\text { Total } \\
\text { Employed }\end{array}$ & $\begin{array}{l}\text { Informal } \\
\text { Sector } \\
\text { Employ- } \\
\text { ment }\end{array}$ & $\begin{array}{l}\text { Under- } \\
\text { employ- } \\
\text { ment rate } \\
\text { (\%) }\end{array}$ \\
\hline Male & $6,149,153$ & $3,302,514$ & $2,603,822$ & $2,391,785$ & $\begin{array}{l}2,021,903 \\
\left(85 \sigma_{\%}\right)\end{array}$ & \\
\hline Female & $6,149,154$ & $3,413,517$ & $2,400,049$ & $2,215,061$ & $\frac{1.215,061}{2,25 \%, 01}$ & 8.4 \\
\hline $15-19$ & $1,502,712$ & $1,500,614$ & 663,283 & 580,688 & 575,484 & 6.7 \\
\hline $20-24$ & $1,134,868$ & $1,134,621$ & 816,244 & 691,613 & $\frac{(99 \%)}{650,550}$ & 7.8 \\
\hline $25-29$ & 979,735 & 980,883 & 830,945 & 760,535 & $\frac{(9940)}{663,882}$ & 8.1 \\
\hline $30-34$ & 779,119 & 779,914 & 694,890 & 657,627 & $\frac{(88 \%)}{548,827}$ & 8.6 \\
\hline $35-39$ & 621,967 & 622,772 & 562,110 & 533,790 & $\frac{148,081}{4481}$ & 8.2 \\
\hline $40-44$ & 449,949 & 450,495 & 408,082 & 392,179 & 327,443 & 8.1 \\
\hline $45-49$ & 338,584 & 339,013 & 309,922 & 298,346 & 249,959 & 9.6 \\
\hline 50.54 & 246,992 & 247,176 & 223,120 & 214,262 & 178,384 & 7.9 \\
\hline $55-59$ & 180,558 & 180,747 & \begin{tabular}{ll|}
57,366 \\
\end{tabular} & 151,288 & 136,909 & 10.8 \\
\hline $60-64$ & 155,609 & 155,541 & 129,893 & 124,497 & $\frac{(9096)}{118,501}$ & 8.3 \\
\hline
\end{tabular}

Source: CSO, Labour Force Survey Report, 2005 and 2008

In order to redress poverty and inequality, the ultimate objective of Zambia's growth and development path over the remaining years of Vision 2030 should be to enable rapid social mobility, with the aim of creating a large middle class, (see [2]). There is substantial agreement from received literature and observed evidence from the developed world, that this could be achieved through the labour market; by forging a growth path that enables the poor, women, and the youth that are exiting the 
education systems, to secure decent paying jobs. Any future growth path that is not labour-absorbing will exacerbate the challenges of poverty and inequality in Zambia.

\section{Sectoral intensity of growth and job creation in Zambia: methodological note ${ }^{1}$}

The most basic definition of employment elasticity is the percentage change in the number of employed persons in an economy or region associated with a percentage change in economic output, measured by gross domestic product. Within this broad definition, two methodologies are frequently utilized for calculating elasticity. The first technique, given in equation 1 below, gives the arc elasticity of employment that is:

$$
\varepsilon=\left(\frac{\left(E_{i 1}-E_{i 0}\right) / E_{i 0}}{\left(Y_{i 1}-Y_{i 0}\right) / Y_{i 0}}\right)
$$

The numerator simply gives the percentage change in employment in country i, Ei, between periods 0 and 1 , while the denominator gives the corresponding percentage change in output, $Y i$. While this methodology is computationally very simple - hence its adoption for the analysis in this paper-Islam [12] have demonstrated that year-overyear employment elasticity calculated using this method tend to exhibit a great deal of instability and may therefore be inappropriate for comparative purposes. The base year or the terminal year may, for example, be abnormal, so that the elasticity obtained may not reflect the 'normal' technological relationship between employment and output for a sector. This problem may be especially severe for a developing country such as Zambia, where the industrial sector is small and the investment incentive programme is predominantly capital centred.

Given this deficiency, another methodology is regularly employed by different authors: the multivariate log-linear regression model. This is given in equation (2).

$\ln \mathrm{E}_{\mathrm{i}}=\alpha+\beta_{1} \ln \mathrm{Y}_{\mathrm{i}}+\beta_{2}\left(\ln \mathrm{Y}_{\mathrm{i}} \times \mathrm{D}_{\mathrm{i}}\right)+\beta_{3} \mathrm{D}_{\mathrm{i}}+\mu_{\mathrm{i}}$

Where, the elasticity of employment with respect to GDP in country $i$ is given by $\beta_{1}+\beta_{2}$. This is calculated by differentiating both sides of equation (2) and solving for $\partial \mathrm{E} / \partial \mathrm{Y}$ :

\footnotetext{
${ }^{1}$ This section benefits in large part from Dopke [11] and Islam and Nazara [12].
}

$\left(\frac{\partial E}{E}\right)=\left(\beta_{1}+\beta_{2}\right)\left(\frac{\partial Y}{Y}\right) \rightarrow \frac{\partial E}{\partial Y}\left(\frac{Y}{E}\right)=\beta_{1}+\beta_{2}$

Using this econometric method, $\beta_{1}+\beta_{2}$ represents the change in employment associated with a differential change in output. Thus, an elasticity of 1 implies that every 1-percentage point of GDP growth is associated with a 1-percentage point increase in employment. An elasticity of 0.4 implies that every 1-percentage point of GDP growth is associated with employment growth of 0.4 percentage points, and so forth.

At this point, it is important to raise a cautionary note regarding the relationship between employment elasticity and labour productivity. There is a fundamental arithmetic identity that links these concepts, which is given by:

$\mathrm{Yi}=\mathrm{E}_{i} \times \mathrm{P}_{i}$

Where $\mathrm{Y}_{i}$ and $\mathrm{E}_{\mathrm{i}}$ are as previously defined-output and employment-and $\mathrm{P}_{i}$ is labour productivity (output per worker). Equation (4) implies that for small changes in output, the following holds:

$\Delta \mathrm{Yi}=\Delta \mathrm{E}_{i}+\Delta \mathrm{P}_{i}$

That is, for a given amount of output growth, $\Delta \mathrm{Y}$, any increase in the rate of employment growth must be met by an equal and opposite decrease in labour productivity growth. In the context of this paper, the significance of this employment elasticityproductivity relationship is great: in formulating conclusions about elasticity, one must necessarily consider the productivity side of the relationship. If we divide equation (5) by output growth, $\Delta \mathrm{Y}$, we derive the following:

$\varepsilon=1-\frac{\Delta P}{\Delta Y}$, where $\varepsilon=\frac{\Delta E}{\Delta Y}$

Using equation (6) with different GDP growth scenarios clarifies the relationship between employment elasticity, $\mathcal{E}$, and actual employment growth and productivity growth.

\subsection{Sectoral employment Intensity of Growth: results and discussion}

In order to compute the employment intensities of growth (or elasticity of employment with respect to output)—a numerical measure of how employment varies with economic output-for Zambia, employment data, disaggregated by economic sectors along with corresponding sectoral value-added data 
for the period 1990 to 2008 were utilized. The sectoral elasticity reveals the extent to which structural transformation translates into employment generation, (see [12]). It is important to note moreover that the trends in calculated employment intensity are only indicative of the response of employment in terms of quantity of employed persons to GDP growth and may not inform to any great extent, the overall changes in the quality of jobs or growth in the number of "decent" jobs created, (see [11]).

Table 4 shows the results of computed sectoral employment elasticity; that is, the percentage changes in employment and output for various sectors over the periods 1990 to 2008, 2000-2005 and 2005-2008, and the estimated employment elasticity they generate. The table reveals that for the economy as a whole, average annual output growth was 3.6 percent in the period 1990-2008, which produced an annual growth in employment of 10.04 percent and a high employment elasticity of 30.63 . This performance, however, was not replicated in the second period: output growth averaged 5.1 percent and employment creation declined even sharper to 7.1 percent, resulting in a lower employment elasticity of 12.51 .

During the third period 2005-2008, annual output growth was 5.9 percent and this generated employment growth of 2.9 percent; an elasticity of only 1.9 percent. However, while employment elasticity were positive and significant for most sectors of the economy during the period 1990-2008, the mining sector and the finance, insurance and business services sectors recorded negative elasticity. This development may of course be due to the capital intensive nature of mining activities and sustained computerization and digitalization of financial intermediation activities. Furthermore, in the manufacturing sector that recorded an output growth of 4.4 and 3.3 percent in the two periods 2000-2005 and 2005-2008, employment

Thus the manufacturing sector might have been creating employment by almost 2.5 percent and 17.1 percent for each percentage increase in output respectively, indicating very high employment elasticity. This could be explained by the nature of industries in manufacturing that included textile that were highly labour intensive.

Other sectors with consistently relatively high employment elasticity included wholesale and retail trade (3.3 and 25.1), construction (0.50 and 2.8) and community, social and personal services $(0.1$ and 58.5), Agriculture (6.44 and 1.9), while mining and quarrying (1.67 and -3.2) and transport and communications $(0.65$ and -0.98$)$ did not repeat the employment-creation they achieved over the period
1990-2008. The finance, insurance and business services sector had relatively low employment elasticity, with each percentage increase in value added giving rise to negative growth in employment over the three periods.

Table 4. Sectoral employment elasticity

\begin{tabular}{|c|c|c|c|c|c|c|c|c|c|}
\hline \multirow{3}{*}{ Sector } & \multicolumn{3}{|c|}{$1990-2008$} & \multicolumn{3}{|c|}{$2000-2005$} & \multicolumn{3}{|c|}{$2005-2008$} \\
\hline & Amanal & 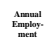 & 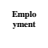 & Ammat & 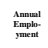 & 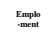 & ${ }_{\text {smanat }}$ & 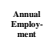 & 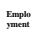 \\
\hline & 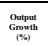 & $\begin{array}{c}\text { cimsuth } \\
\text { (sis) }\end{array}$ & 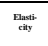 & 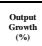 & $\begin{array}{c}\text { cimsuth } \\
\text { (sis) }\end{array}$ & 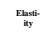 & 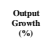 & 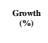 & 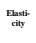 \\
\hline 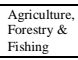 & 3.3 & 17.2 & 4.6 & 1.2 & 7.01 & 6.44 & 1.2 & 2.52 & 1.91 \\
\hline 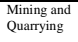 & -0.2 & 3.39 & -2.9 & 7.7 & 17.17 & 1.67 & 5.3 & $\begin{array}{l}-11.03 \\
\end{array}$ & .3 .2 \\
\hline 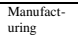 & 3.6 & 4.6 & 0.9 & 4.4 & 11.71 & 2.54 & 3.3 & 46.71 & 17.2 \\
\hline 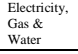 & 1.5 & 2.09 & 1.3 & 2.6 & 2.87 & 1.15 & 3.9 & -24.13 & -9.4 \\
\hline $\begin{array}{l}\text { Construcl- } \\
\text { ion }\end{array}$ & 10 & 8.91 & 0.4 & 15.8 & 13.13 & 0.48 & 16.1 & 35.07 & 2.85 \\
\hline $\begin{array}{l}\text { Wholesale, } \\
\text { Retili } \\
\text { hotels \& }\end{array}$ & 6.1 & 37.6 & 5.8 & 7.3 & 16.16 & 3.33 & 6.5 & 65.72 & 25.1 \\
\hline 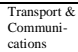 & 6.8 & 5.39 & 0.5 & 9.6 & 8.49 & 0.65 & 17.0 & -16.77 & -0.9 \\
\hline 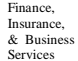 & 5.1 & -.3 .34 & -0.5 & 4.2 & -4.0 & .1 .08 & 4.1 & $\begin{array}{l}-16.71 \\
\end{array}$ & .5 .1 \\
\hline 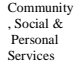 & 4.1 & 4.91 & 0.91 & 6.0 & 0.71 & 0.08 & 11.1 & 539.5 & 58.5 \\
\hline 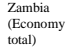 & 3.6 & 10.04 & 39.6 & 5.1 & 7.09 & 12.5 & 5.9 & 2.88 & 1.92 \\
\hline
\end{tabular}

Sources: CSO 2005, 2008 and author's computation

It therefore follows that tackling Zambia's youth unemployment problem means focusing attention on removing the impediments to growth in the sectors with relatively high employment elasticity, especially manufacturing, wholesale, retail trade, hotels and restaurants, and community, social and personal services. Thus, manufacturing and tourism, if properly supported to grow, would as per theory and observed situation in the developed world, take a leading role in terms of contribution to employment, [20].

\section{Summary and conclusions}

Reviewed statistics reveal that Zambia's economic growth of the last two decades has not translated into significant poverty reduction, neither has the surge in FDI inflows resulted in significant reduction in unemployment levels. Sixty percent of the population still lives below the poverty line, and 42 percent are considered to be in extreme poverty. About 300000 young people enter the labour market each year in Zambia with few employment opportunities to absorb them. Obstacles to youth employment include the inability of the educational system to equip people with relevant skills required by the job market, high school dropout rates, lack of entrepreneurial opportunities, and poor access to 
labour market information for job seekers and employees.

The results of our analysis of employment intensities reveal a mixed picture. While employment elasticities were positive and significant for most sectors of the economy during the period 1990-2008, the mining, and the finance, insurance and business services sectors recorded negative elasticities. This implies declining propensities to generate employment over the 2-decade period by the mining and finance sectors. An explanation for this could be found in the capital intensive nature of mining activities and sustained computerization and digitalization of financial intermediation in Zambia. Furthermore, in the manufacturing sector that recorded annual output growth of 4.4 and 3.3 percent over the two periods 2000-2005 and 2005-2008, employment increased by 11.7 and 46.7 percent respectively. Thus, the manufacturing sector was creating employment by almost 2.5 percent and 17.1 percent for each percentage increase in output respectively, indicating very high employment elasticities.

From the foregoing, policy measures to tackle Zambia's unemployment (of the youth in particular) problem would revolve around such that could remove the impediments to growth in sectors with relatively high employment elasticity; manufacturing, wholesale, retail trade, hotels and restaurants, and community, social and personal services. In actual fact, these sectors are being ascribed the characteristics of possessing special "employment-pulling" and/or "growth-enhancing" properties, in the development literature. It is therefore important that to make growth more inclusive and job-rich, one of the macroeconomics objectives in Zambia's Vision 2030, these sectors, manufacturing and most probably high-valueaddition agricultural activities, where agriculture remains the highest employer of labour-formal and informal-requires priority attention in terms of growth enhancing and diversification policies and strategies. Similarly, the roles of the private sector and CSOs in driving employment creation have to be more clearly defined and formalized in social compacts.

\section{References}

[1] Ravallion, M., 'What is needed for a more pro-poor growth process in India? Economic and Political Weekly, 35(13), 2000, pp. 1089-1093.

[2] Republic of Zambia, 'Vision 2030: A Prosperous Middle-Income Nation by 2030', Ministry of Finance, Lusaka, 2006.
[3] Loayza, N. and Raddatz, C., 'The composition of Growth Matters For Poverty Alleviation,' Mimeo, World Bank, Washington, DC, 2006.

[4] Satchi, M. and Temple, J., 'Growth and Labour Markets in Developing Countries', Department of Economics, University of Bristol Discussion Papers, Bristol, 2006.

[5] Okun, A., 'Potential output: Its measurement and significance,' Proceedings of the Business and Economic Statistics Section of the American Statistical Society, and reproduced in Okun, A. (ed.), 1970, 'The Political Economy of Prosperity', Washington, DC, 1962.

[7] Prachowny, M.J.F., 'Okun's law: Theoretical Foundations and Revisited Estimates', Review of Economics and Statistics, 75: 1993, pp. 331-336.

[8] Gabrisch, H. and Buscher, H., 'The Unemploymentgrowth Relationship in Transition Countries, IWH Discussion Paper, No. 5, Halle Institute for Economic Research, Halle Institute for Economic Research, Halle, 2005.

[9] Perugini, C., 'Employment Intensity of Growth in Italy: A Note Using Regional Data', Regional and Sectoral Economic Studies, 9 (1), 2009, pp. 59-105.

[10] Kapsos, S, 'The Employment Intensity of Growth: Trends and Macroeconomic Determinants', Employment Strategy Papers, Employment Determinants Department, ILO, Geneva, 2005.

[11] Dopke, J., 'The Employment Intensity of Growth in Europe', Kiel Working Paper, No. 1021. Kiel Institute of World Economics, Kiel, 2001.

[12] Islam, I and Nazara, S., 'Estimating Employment Elasticity for the Indonesian Economy', Technical Note on the Indonesian Labour Market, ILO Office, Jakarta, 2000.

[13] Ajilore, $\mathrm{T}$ and Yinusa O., 'An Analysis of Employment Intensity of Sectoral Output Growth in Botswana', Southern African Business Review, 15 (2) 2011, 2011, pp. 26-42.

[14] World Bank, 'Global Economic Prospects 2014', World Bank, Washington DC, 2014.

[15] International Labour Office (ILO), 'A Skilled Workforce for Strong Sustainable and Balanced Growth: A G20 training Strategy', International Labour Office, Geneva, 2010

[16] African Development Bank (AfDB), 'African Economic Outlook 2014: Global Value Chains and Africa's Industrialisation', African Development Bank, Tunis and OECD, Paris, 2014.

[17] Central Statistics Office (CSO), 'Labour Survey Report 2005', CSO, Lusaka, 2006. 
[18] Central Statistics Office (CSO), 'Labour Survey Report 2008', CSO, Lusaka, 2009.

[19] African Development Bank, (AfDB), 'The Middle of the Pyramid: Dynamics of the Middle Class in Africa', the Chief Economist Complex, Market Brief, April 20, AfDB, Tunis, 2011.

[19] Central Statistical Office (CSO) (2012), 'Zambia 2010 Census of Population and Housing Summary Report', CSO, Lusaka, 2012.

[20] Siphambe H.K., 'Growth and Employment Dynamics in Botswana: A Case Study of Policy Coherence', Working Paper No. 82, Policy Integration and Statistics Department ILO, Geneva, 2007. 